\author{
VALENTIN CONSTANTINOV* \\ Institutul de Istorie \\ Academia de Ştiinţe a Moldovei, Chişinău \\ ORCID: 0000-0001-9578-1134
}

\title{
WOJNA O TRON HOSPODARSKI W MOLDAWII W LATACH 1615-1616 I JEJ WPLYW NA STOSUNKI POLSKO-OSMAŃSKIE
}

Wydarzenia w Mołdawii w końcu I6I5 i w pierwszej połowie I6I6 roku były zdominowane przez walki zbrojne o tron hospodarski. Po kilku latach względnego spokoju wybuchła ponownie walka pomiędzy mołdawskim hospodarem Stefanem Tomżą II a jego polsko-mołdawskimi nieprzyjaciółmi ${ }^{1}$. Jesienią roku I6I5 w Mołdawii wybuchło powstanie bojarów mołdawskich. Ich celem było zrzucenie z tronu hospodarskiego ówczesnego hospodara Tomży. Rozstrzygnięcie nastąpiło w bitwie pod Fântâna (Krynica) lui Păcurar w połowie października I6I5 r. Tym razem dzięki wsparciu mieszczan stolicy mołdawskiej, Jass, Tomża zwyciężył. Jednak już wtedy było wiadomo, że w Uściu² - posiadłości rodziny Mohyłów gromadzono nową armię z zamiarem wkroczenia do Mołdawii i przejęcia władzy, utraconej przez ten ród w I6II $\mathrm{r}$.

W historiografii mało powiedziano o związku między tymi wydarzeniami - kampanii polskiej i powstaniu bojarów przeciwko hospodarowi mołdawskimu - jednak można przypuścić, że były one ścisłe. Żądanie ze strony bojarów, żeby Tomża opuścił tron hospodarski nie mogło się pojawić bez pojawienia się pewnego następcy. A ponieważ w historiografii nie wiadomo, na kogo mogli powstańcy liczyć jako na kolejnego hospodara, przypuszcza się, że brano pod uwagę właśnie Aleksandra Mohyłę.

W czasie powstania bojarów mołdawskich, książę Siedmiogrodu, Gabor Bethlen, pisał, że w okolicach Chocimia już znajduje się armia polska³. Prawdopodobnie już wtedy

\footnotetext{
* Dr hab. Valentin Constantinov, wykładowca w Instytucie Historii Mołdawskiej Akademii Nauk w Kiszyniowie. E-mail: walentkonstant@yahoo.fr.

1 Patrz moje artykuły: Bitwa pod Sasowym Rogiem i jej wplyw na relacje polsko-osmańskie w 1612 roku, w: Wybrane problemy badawcze historii wojskowej. W pancerzu i mundurze, red. K. Kościelniak, Z. Pilarczyk, Toruń 2014, s. 101-127; Stosunki polsko-mołdawskie za czasów hospodarstwa Stefana Tomszy II (1612-1615), ,Saeculum Christianum", 21/2014, s. 114-120; The political and military realities Nothward Danube in 1612, w: Studia z dziejów stosunków z Państwem Moskiewskim w XVI-XVII wieku, red. M. Nagielski, Zabrze-Tarnowskie Góry 2013, s. 148-162.

Dziś Ustia Zelene, obwód Ternopil-Ukraina.

Documente privitoare la istoria Ardealului, Moldovei şi Ţării Româneşti, red. A. Veress, t. 9: 1614-1636, Acte şi scrisori, red. A. Veress, Bucureşti 1936 [dalej: Veress 9], s. 52-53, nr 45.
} 
obaj perkułabowie chocimscy poddali się Polakom ${ }^{4}$, a twierdza ponownie stała się polska 5 . Poseł holenderski w Konstantynopolu pisał, że agenci hospodara powiedzieli Turkom, że powstańcy, czyli mołdawscy bojarzy, mieli umowy z Polakami, a ci ostatni stoją na granicy i mają ze sobą brata Konstantego Mohyły, byłego hospodara zrzuconego z tronu przez Tomżę .

Chociaż Stefanowi Tomży udało się uporać z powstaniem bojarów mołdawskich, czymś zupełnie innym był problem z wojskiem polskim, niezależnie od tego, że składało się ono z prywatnych oddziałów, zebranych głównie przez Michała Wiśniowieckiego i Samuela Koreckiego. Ani król, ani hetman polny koronny Stanisław Żółkiewski nie wspierali idei nowej kampanii wojennej, która nie miała szans powodzenia, a mogła przynieść duże kłopoty Rzeczypospolitej. Kolejnym powodem takiego podejścia do problemu mołdawskiego były priorytety w polityce zagranicznej Zygmunta III, a razem z nim i hetmana polnego, który wspierał każdy krok króla w tej kwestii. Głównym problemem dla Zygmunta III Wazy była sprawa moskiewska, gdzie miał nadzieję na utwierdzenie na tronie moskiewskim swego syna, Władysława. Z kolei sam hetman polny miał własne plany co do osoby, która musiała zająć tron hospodarski Mołdawii. Stawiał na Gabriela Mohyłę, który mieszkał kilka lat u hetmana w Żółkwi, a pochodził z linii Szymona Mohyły, brata Jeremiego Mohyły.

Jednak, jak się wydaje, więcej zwolenników mieli polscy zięciowie Elżbiety Mohyłowej, wdowy po Jeremim. Udało im się zebrać armię, której nie mógł sprostać hospodar mołdawski, który nie miał możliwości utrzymywania dużej armii. Ograniczały go względy finansowe oraz działania władz tureckich, które dbały o to, żeby armie hospodarów Mołdawii i Wołoszczyzny nie były za duże, a Turcy nie mieli kłopotów z kolejnymi powstaniami. Tak było za czasów Michała Walecznego, a także podczas ostatniej wojny „wasalów” w I6II r., kiedy działania Gabriela Batorego i odpowiedzi zbrojne Radu Szerbana i Konstantego Mohyły wywołały wielkie problemy na północ od Dunaju?

W tej sytuacji Wiśniowiecki i Korecki musieli przekonać swoich zwolenników, ale przede wszystkim przeciwników politycznych, którzy byli liczni i potężni. Przed kampanią mołdawską Żółkiewski wydał uniwersał, w którym krytykował działania magnatów na terenie Mołdawii. Pisał w nim, że, korzystając z sytuacji w Mołdawii, Elżbieta Mohyłowa zechciała ponownie zdobyć tron hospodarstwa dla swego syna. Z powodu tych działań Polskę czeka dużo kłopotów ze strony Turków ${ }^{8}$. Zachowanie się żołnierzy zaciężnych i rabunki ludności

\footnotetext{
4 Ch. Joppecourt, Istoria scurtă şi adevărată a celor mai memorabile lucruri întâmplate în tulburările din urmă ale Moldovei, w: A. Papiu Ilarian, Tesauru de monumente istorice pentru România, t. 2, Bucureşti 1863, s. 26 [dalej: Tesaur 2].

5 W okresie między 1611-1621 twierdza chocimska kilkanaście razy zmieniła swych właścicieli, będąc odpowiednio w latach: 1611 - mołdawska; 1612 - polska; 1614 - mołdawska; 1615 - polska; 1617 - mołdawska; 1620 polska; 1621 - mołdawska. (O tych zmianach: V. Constantinov, Cetatea Hotinului în disputele politico-militare polono-otomane din perioada 1612-1621, "Cohorta", 2015, nr 1, s. 41-56).

6 N. Iorga, Doamna lui Ieremia vodă, „Analele Academiei Române. Memoriile Secţiunii Istorice”, seria II, t. 32/1910, s. 1063, nr 22.

$7 \quad$ V. Constantinov, Działania wojenne $w$ państwach rumuńskich $w$ roku 1611 i ich konsekwencji $w$ owczesnych stosunkach polsko-tureckich, w: Studia historyczno-wojskowe, t. 1, Siedlce 2006, s. 49-56.

$8 \quad$ Pisma Stanisława Żółkiewskiego, wydał A. Bielowski, Lwów 1861, s. 242-246, nr 45.
} 
cywilnej ${ }^{9}$ doprowadziły do poważnych zniszczeń ${ }^{10}$. Wojewoda ruski Jan Daniłowicz pisał o tych rozruchach i o niebezpieczeństwie odwetu ze strony Turków ${ }^{\mathrm{II}}$.

Wiedząc o zbliżaniu się wojska polskiego, Tomża przywołał do siebie kapitanów z pogranicza siedmiogrodzkiego. Jednak oni mogli dać pomoc tylko za pozwoleniem samego księcia siedmiogrodzkiego, Gabora Bethlena. On zaś im nie pozwolił, bo oczekiwał na prośbę od samego Tomży. Później powiedział, że Tomża nie poprosił o pomoc ani jego, ani hospodara Wołoszczyzny Radu Mihni ${ }^{12}$.

Już w połowie listopada armia polska znajdowała się w Mołdawii, a w dniach 22-23 tego miesiąca rozegrała się główna bitwa tej kampanii. Toczyła się ona w Tatarenach, w odległości kilkunastu kilometrów od Jass, stolicy ówczesnego państwa mołdawskiego. Wobec braku wsparcia ze strony hospodara Wołoszczyzny, księcia siedmiogrodzkiego, a także i Tatarów z Krymu, Stefan Tomża został pokonany. W następnym dniu, główny dowódca armii polskiej w liście do swojej teściowej opisał bitwę, po której Mohyłowie ponownie zajęli tron hospodarski w Mołdawii. List podaje liczbę żołnierzy polskich - 6ooo. Liczba żołnierzy, którzy walczyli na stronie Tomży, jest znacznie zawyżona - 20000: „Miał wojska pewnie dwadzieścia tysięcy między któremi Tatarów i Turki pięć, piechoty węgierskiej choć na trzy tysiące było prócz nacyi rozmaitych jemu pobliskich jako Multanów, Serbów...”’3. Wkrótce po bitwie Adam Sieniawski pisał do króla, żeby ten wsparł dyplomatycznie działania wojskowe Wiśniowieckiego i Koreckiego na terenie Mołdawii ${ }^{14}$. Już po bitwie przy Tatarenach, I grudnia I6I5, w Haliczu ${ }^{15}$ i Kołomyi ${ }^{16}$ sejmiki uchwaliły odpowiednie decyzje. W kwestiach

\footnotetext{
9 „K temu że i to drugie niebespieczeństwo nas nie po mału zachodzić musi że najdują się tacy miedzy nami bracia naszy swawolni, którzy minąwszy prawo pospolite, nie mając w tem przedsięwzięciu swem żadnego pozwolenia J. K. Mci, rad koronnych do wojny i inszych w takim razie Rzptej naszej należących privata autoritate chorągwie swe in contemptum superioritatis rozciągają, kupy wielkie ludzi zbierają, onemi braci naszej i nam samym w majętnościach szkody czynią ...": Akta Grodzkie i Ziemskie z Archiwum Ziemskiego we Lwowie [dalej: AGZ], t. 24: Lauda Sejmikowe Halickie (1575-1695), wyd. A. Prochaska, Lwów 1931, s. 25-26, nr 18.

10 W. Łoziński, Prawem i lewem. Obyczaje na Czerwonej Rusi w pierwszej połowie XVII wieku, Warszawa 2008, w rozdziale ,Żołnierz swawolny” opisuje przypadki takiego rodzaju.

11 AGZ, t. 20, s. 150, nr 102; s. 151-152, nr 104.

12 Veress, 9, s. 59, nr 49.

13 List został napisany 24 listopada. Biblioteka PAN w Kórniku [dalej: B.PAN Kórnik], rkps nr 324, k. 187v-188r.

14 „Uniżenie WKM smiałbym prosic abyś iako Pany głowa nasza predko Mciwą łaską Alexandra y wszytek ten Dom wesprzec raczył a Posłem swym predko do Constantynopola poprzedzieł iakobyś WKM y tę Ziemię zatrzymac y bespieczenstwo Rptey obwarowac raczył" (B.PAN Kórnik, rkps nr 324, k. 188r).

15 AGZ, t. 24, s. 18, nr 19: „Na tym tedy placu doszła nas nowina z Wołoch, że się tam już conflictus 23 die Novembris pod Jasami stał i z łaski Bożej stetit victoria za tymi, którzy Tomszę z tego państwa zepchnąć usiłują. Jednak iż ta victoria nie jest determinata abychmy mieli sobie obiecować cettissimam securitatem, bo jeszcze ten nieprzyjaciel w ręce zwyciężcam nie przyszedł, zaczem vivus hostis isto vulnere nie tak już podobno straci nadziei wszystkiej, aby nie miał iterum fortunam belli tentare, które suas vicissitudines zwykła miewać. Do tego jest i druga animadwerzya, jeśli Alexandrowi Mohile dadzą od Porty cesarza Tureckiego chorągiew albo nie, albo jako rychło, tedy póki te rzeczy się nie skończą zawsze jako prede drzwiami w tych krajach niebezpieczeństwo... i owszem póki firmam tranquillitatem tamtej ziemi Wołoskiej nie usłyszymy, in armis być w pogotowiu...”.

16 Ibidem, s. 29-30, nr 20: „A iż przy konzultacyach naszych zaszła nas t awiadomość. Iż w ziemi Wołoskiej Imc p. Alexander Mohyła Stefana Tomszę wiktoryą otrzymał, a na stolicy ojca swego osiadł, za czem się pokoju pod ten czas spodziewamy, do domów naszych rozjechać się rozumieliśmy- ale że sobie pewnego i długiego pokoju ze dwóch przyczyn nie możemy, pierwsza iż aemulus nowego hospodara zdrów cum nervo bellico uszegt, który iż tentare może belli fortunam rzecz jest podobna; wtóra iż o daniu chorągwie u Porty cesarza tureckiego jest wątpliwość, tak się rozjeżdżając ubezpieczamy, iż uchowaj Panie Boże na Alexandra Imc nowego hospodara wstrętu i odmiany fortuny, a stąd na granice niebespieczeństwa...".
} 
mołdawskich sejmiki stwierdzały, że pokój nie jest pewny, dopóki Aleksander Mohyła nie otrzyma chorągwi od sułtana tureckiego. A co do tego właśnie była wątpliwość.

Kwestie mołdawskie wzbudziły zainteresowanie Siedmiogrodzian. Książę Gabor Bethlen pisał o wydarzeniach na wschodzie do mieszczan Bystrzycy ${ }^{17}$. 7 grudnia I6I5 r. Szymon Pechy pisał do barona Ioana Molarta o wygnaniu Tomży, który znalazł schronienie w Braile ${ }^{\mathrm{I}}$. Bailo Wenecji w Konstantynopolu informował, że Tomża wysłał list sułtanowi, w którym pisał o swoim stanie, a polscy agenci w stolicy Imperium Osmańskiego twierdzili, że król Zygmunt III Waza nie miał żadnego udziału w sprawach mołdawskich ${ }^{19}$. Do innych dworów europejskich dotarła informacja dotycząca Mołdawii: zaczęły się tam kolejne starcia militarne, a król polski ma w tym własny interes ${ }^{20}$. Ogólnie w stolicy Imperium Osmańskiego myślano, że do kampanii mołdawskiej doszło na polecenie i ze wsparciem króla ${ }^{21}$. Jednak ci sami dyplomaci pisali, że Turcy mają zamiar dalej wspierać Tomżęe2. Ze kolei hospodar Wołoszczyzny, Radu Mihnea ${ }^{23}$, miał wielkie obawy, że książęta polscy mogliby kontynuować swoją kampanię i na Wołoszczyźnie ${ }^{24}$.

Na początku nowego hospodarstwa, pomimo że władze osmańskie nie miały zamiaru zaakceptować zmiany na tronie mołdawskim, rząd mołdawski zadecydował, że musi wysłać do stolicy Imperium Osmańskiego należyty haracz. Miało to przekonać Turków, że nowy hospodar będzie im przychylny i utrzyma porządek w państwie. W tych samych kręgach dyplomatycznych konstantynopolitańskich informowano o dalszych działaniach na terenie Mołdawii25. Poseł ze strony Polaków - co prawda nie wiadomo, do jakiego obozu

\footnotetext{
17 Documente privitoare la istoria românilor, culese de Eudoxiu Hurmuzaki, t. 15: Acte şi scrisori din arhivele oraşelor ardelene (Bistriţa, Braşov, Sibiu), red. N. Iorga, cz. 2: 1601-1825, Bucureşti 1913 [dalej: Hurmuzaki-Iorga, 15, cz. 2], s. 864, nr 1725; s. 864-865, nr 1626.

18 Veress, 9, s. 63, nr 53: „cum uxore, liberis, amplissimoque thesauro Braylam ad ripam Danubii locatam secessit, ibi Turcarum, si poterit auxilium imploraturus".

19 „ma l'agente qui del Re di Pollonia afferma, che di cio Sua Maesta non habbia parte alcuna”. W liście tym mówi się dalej, iż ta wiadomość wprawiła wielkiego wezyra w wielkie zmieszanie (Documente privitoare la istoria românilor, culese de Eudoxiu Hurmuzaki, t. 4, cz. 2 (1600-1650) [dalej: Hurmuzaki, 4, cz. 2], Bucureşti 1884, s. 350, nr 374).

20 Sansy do Puisyeulx, 12 XII 1615, w: Documente privitoare la istoria românilor, urmare la colecţiunea lui Eudoxiu Hurmuzaki, supliment 1, t. 1: 1518-1750, red. Gr. G. Tocilescu, A. I. Odobescu, Bucureşti 1886, nr 256, s. 165-166. ) [dalej: Hurmuzaki, supl. 1, t. 1].

21 N. Iorga, Doamna lui Ieremia Movilă..., s. 1061, nr 20.

22 Hurmuzaki, 4, cz. 2, s. 351, nr 375.

23 Trochę później, pisząc o kwestii mołdawskiej, Stanisław Tarnowski, kasztelan sandomierski, 10 lutego 1616 r. pisał do Zbigniewa Ossolińskiego wojewody sandomierskiego, że po zwycięstwie nad Stefanem Tomżą, Radu Mihnea wysłał poselstwo do Samuela Koreckiego, prosząc, żeby nie zaatakował jego państwa: „Wiecz dostałby byl Tomszę, ale woiewoda multanski zwlokł go do trzeciego dnia traktatami ...A zwlokł tym kształtem: prosil aby do ziemie iego nie wchodzil z takiem woiskiem, obiecuiąc poimac Tomszę i wydac go" (Documente privitoare la istoria românilor urmare la colecţiunea lui Eudoxiu de Hurmuzaki, supliment 2, t. 2: 1601-1640, red. I. Bogdan, thum. francuskie I.Skupiewski, Bucureşti 1895 ) [dalej: Hurmuzaki, supl. 2, t. 2], s. 392, nr 200).

24 Almoro Nani bail do godiego Wenecji, 9 I 1616: „essi Polachi il favor della fortuna, non tentassero di penetrare anco nel suo paese" (Hurmuzaki, 4, cz. 2, s. 352, nr 376).

25 „diccono appresso li suddetti messi espediti dal Vallacco «Radu Mihnea n.ns.» che Alessandro novo Principe di Bogdania ha mandato a roccogliere per tutto il paese il tributo per far denari, publicando di volerli mandare alla Porta per mostrar la sua devotione et per far sapere insieme, che quello che ha fatto non e stato con altro fine, che per far vendicarsi della morte, che Steffano diede a Costantin Vaivoda suo fratello che nel resto vuol essere come fu Hieremia Vaivoda suo padre, fedelissimo, et ossequentissimo servitore della Maesta Sua «Turecki sultan n.ns.»" (ibidem, s. 352, nr 376).
} 
należał - został przyjęty bardzo zimno, a dotarł do Konstantynopola w kompanii Krystofora Brutti $^{26}$. Turcy mieli zamiar przywrócić Tomżę na tron hospodarski ${ }^{27}$.

Próba zebrania haraczu napotkała jednak na trudności. Nie wszyscy obywatele Mołdawii uznawali Aleksandra za hospodara z powodu braku chorągwi tureckiej. W końcu haracz został wysłany, jednak to nadal nie gwarantowało Mohyłom hospodarstwa. Kozacy, którzy nie otrzymali należytego żołdu, zdezerterowali, a po drodze zniszczyli dwa powiaty, w tym Orchei. Doszło również do kilku starć z ludnością miejscową, w których Polacy zwyciężyli ${ }^{28}$.

Kampania przywrócenia Tomży na tron hospodarski zaczęła się w styczniu I6I6 r. ${ }^{29}$. Obawom hospodara Wołoszczyzny co do możliwego ataku ze strony książąt polskich towarzyszyło wielkie niezadowolenie Siedmiogrodzian z gromadzenia wojska na kampanię mołdawską, gdyż mogło to doprowadzić do konfliktu z Polakami ${ }^{30}$. Próby przekupienia osmańskich dygnitarzy nie dały żadnych rezultatów ${ }^{31}$.

Kolejna faza wojny o hospodarski tron toczyła się pod Chocimiem. Odeszła tam armia książąt polskich i zdecydowała się bronić. Sytuacja była bardzo skomplikowana. Wśród wołoskich bojarów pojawiła się grupa, która zaczęła tajne rozmowy o osadzeniu na tronie hospodarskim ich faworyta Radu Szerbana, obalonego jeszcze w I6II r. Ten sam Szerban prosił w tym samym czasie o sfinansowanie własnej kampanii dla odzyskania tronu Wołoszczyzny ${ }^{32} .2$ marca I6I6 r. Radu Szerban pisał do arcyksięcia Maksymiliana Habsburga o planach odzyskania tronu hospodarskiego ${ }^{33}$.

Po tym jak opuścił Jassy, Aleksander Mohyła wysłał nowy list do wielkiego wezyra, przypominając o obietnicy danej jego ojcu, że tron mołdawski zawsze będzie należał do Jeremiego i jego spadkobierców po mieczu ${ }^{34}$. Bailo Wenecji w Konstantynopolu pisał, że posłowie Aleksandra mieszkali u ambasadora Francji z listem adresowanym do wielkiego wezyra. Tymczasem na początku marca I6I6 r. Tomża ponownie był hospodarem w Jassach. Hospodar Wołoszczyzny Radu Mihnea zostawił mu IOoo żołnierzy i wrócił do siebie ${ }^{35}$.

Działalność dyplomatyczna administracji hospodarskiej Aleksandra Mohyły była bardzo szeroka, jednak mało skuteczna. Podczas poselstwa do Radu Mihnii, ówczesnego hospodara Wołoszczyzny, ten powiedział że: „Aleksander zna moc, którą sułtan ma na niego (Radu Mihnię), i on tej mocy nie może sprzeciwić się, ani jego paszom... nie chciałby pomóc Stefanowi (Tomży) gdyby nie rozkaz sułtana"36. Gabor Bethlen książę siedmiogrodzki dał podobną

\footnotetext{
${ }_{26}$ O tych dragomanach zob.: A. Pippidi, Quellques drogmans de Constantinople au XVIIe siecle, "Revue des Etudes Sud-Est Europeenes", 10/1972, nr 2, s. 240-241.

27 Hurmuzaki, 4, cz. 2, s. 353, nr 377.

28 Patrz wyżej wspomniany list Tarnowskiego do Ossolińskiego. Hurmuzaki, supl. 2, t. 2, s. 391-392, nr 200.

29 Wtedy hospodar Wołoszczyzny Radu Mihnea znajdował się w miaście Buzau, blisko granicy mołdawskiej i pisał do pewnego Siedmiogrodzianina o wysłaniu konia: Veress, 9, s. 64-65, nr 55; 65-68, nr 56.

30 Veress, 9, s. 70, nr 58.

31 N. Iorga, Doamna lui Ieremia Movilă..., s. 1063, nr 25.

32 Veress, 9, s. 71-72, nr 61. „Venerunt diversi homines et literae a tota nobilitate ac cetera gente totius provinciae Valachiae Transalpinae offerentes fidelitatem Vrae Mti et mihi devotionem promittentes". Z drugiej strony w tym samym czasie byli oskarżani o zdradę Lupu wielki logofet, Leka wielki miecznik itd. Tesaur 2, s. 59. V. Constantinov, Țara Românească și Țara Moldovei în timpul domniilor lui Radu Mihnea, Iași 2007, s. 84, 93.

33 N. Iorga, Studii şi documente cu privitoare la istoria românilor, t. 4, Bucureşti 1902, s. 170-171, nr 26.

3420 II 1616: Hurmuzaki, 4, cz. 2, s. 354, nr 378.

35 Hurmuzaki, 4, cz. 2, s. 355, nr 379.

36 Tesaur 2, s. 43-44.
} 
odpowiedź na poselstwo ze strony władz mołdawskich, które oskarżały go o udzielenie pomocy Tomży37, gdy nie odmówił Osmanom i uczestniczył w kampanii o przywrócenie Tomży na tron hospodarski na początku i6ı6 r. Oczywiście nie można mówić o tym, że sam młody hospodar mógł wtedy podejmować decyzje, jednak jego doradcy wiedzieli bardzo dobrze, jak funkcjonuje osmański system polityczny ${ }^{3}$. Właśnie dlatego podjęli działania, które być może w innych okolicznościach doprowadziłyby do sukcesu. Czas nie był jednak sprzyjający. Wygnanie Tomży z hospodarskiego tronu Mołdawii przez potężną armię nie było do zaakceptowania przez władze tureckie. Warunki polityczne również były inne niż w roku $1595^{39}$, kiedy to Polakom udało się narzucić Osmanom podwójne zwierzchnictwo polsko-osmańskie nad Mołdawią.

Żeby dokładnie zrozumieć, co się stało później, musimy spojrzeć uważnie na rzeczywistość, która zaistniała wtedy w Mołdawii. Chociaż pierwszy okres hospodarstwa Aleksandra Mohyły nie trwał więcej niż kilka miesięcy, jego administracji udało się zebrać haracz i wysłać go do Konstantynopola. To znaczy że przynajmniej część zebranych podatków została do dyspozycji tej samej administracji, co mogło dać możliwość wykorzystania tego w przyszłości. Tak możemy również objaśnić to, jak Mohyłom udało ponownie wygnać Tomżę i osiągnąć władzę w Mołdawii.

Po przywróceniu Tomży na tron hospodarski, Gabor Bethlen napisał dygnitarzom osmańskim, że dalej nie będzie pomagał hospodarowi mołdawskiemu ${ }^{40}$. Z drugiej strony, możliwość wielkiej wojny polsko-osmańskiej niepokoiła polską szlachtę. W wyniku rabunków Kozaków, którzy szykowali się do wkroczenia do Mołdawii, wojewoda podolski Stanisław Lanckoroński proponował Zbigniewowi Ossolińskiemu omówić sprawę mołdawską: „Proszę racz W.M. mój mciwy pan na sejmiku tamtym tę proponować sprawę, niechaj my starożytna szlachta dla indygenatów wołoskich i szwagrów ich nie niszczejemy"\$r. Wśród innych oddziałów, które pustoszyły obrzeża Rzeczypospolitej znajdował się i ten który należał do przyszłego hospodara mołdawskiego - Mirona Barnowskiego ${ }^{42}$.

Sytuacja zmieniła się w kwietniu I6ı6 r. Armia polska wytrzymała nacisk koło Chocimia, a później przeszła do ofensywy, i w kilku starciach Polacy zwyciężyli. 8 kwietnia I6I6 r. Stanisław Tarnowski pisał wojewodzie sandomierskiemu o zwycięstwie Koreckiego nad oddziałem tureckim³. I2 kwietnia I6ı6 r. Krzysztof Valier bailo Wenecji pisał do doży że, Stefan Tomża II stracił ponownie tron Mołdawii i uciekł na Wołoszczyznę. Mając nadzieję

\footnotetext{
37 Ibidem, s. 43.

38 Najważniejszym był Nestor Ureki, ojciec Jerzego Urekiego pierwszego wybitnego mołdawskiego kronikarza.

39 D. Milewski, A campaign of the great hetman Jan Zamoyski in Moldavia (1595), cz.1: Politico-diplomatic and military preliminaries, „Codrul Cosminului”, 18/2012, nr 2, s. 261-286; idem, A Campaign of the great hetman Jan Zamoyski in Moldavia (1595), cz. 2: The Battle of Ţuţora and aftermath, „Codrul Cosminului”, 19/2013, nr 1, s. 57- 76. O systemie politycznym podwójnej zwierzchności patrz: C. Bobicescu, Intre integrare și păstrarea autonomiei. Modelul polonez și controlul domnilor în Moldova și Țara Românească la cumpăna secolelor XVI-XVII, w: Movileştii. Istorie şi spirituallitate românească. T.II. Ieremia Movilă. Domnul. Familia Epoca, Suceviţa 2006, s. 227-248.

40 Almoro Nani do doży Wenecji, 19 III 1616: „Ho inteso anco da buona parte che sono venute lettere di Transilvania di Betthelem Gabor pur al Caimecan nelle quali scrive che cessando l'occasione non andera più in aiuto di Steffano Vaivoda" (Hurmuzaki, 4, cz. 2, s. 356, nr 380).

${ }^{41}$ Hurmuzaki, supl. 2, t. 2, s. 396-397, nr 203.

42 O nim patrz: D. Milewski, Mołdawia między Polską a Turcją. Hospodar Miron Barnowski i jego polityka (1626-1629), Oświęcim 2014. A także aneks źródłowy nr 1.

43 Do bitwy doszło pod Chocimiem: Hurmuzaki, supl. 2, t. 2, s. 398, nr 204.
} 
go schwytać, armia polska weszła na Wołoszczyznę44. 25 kwietnia I6ı6 r., Gabor Bethlen pisał do kapitana Andrzeja Doczy o nowej zmianie na tronie Mołdawii. Pisał i o wejściu polskiej armii na Wołoszczyznę45. W końcu kwietnia I6ı6 r. Aleksander wydawał nowe akty jako hospodar Mołdawii ${ }^{46}$.

Szczegóły najazdu na Wołoszczyznę zostały opisane przez francuskiego żołnierza Charlesa Joppecourta. Polacy starali się złapać Tomżę wygnanego z Jass. Doszli do granicy Wołoszczyzny i poszli dalej. Garnizon wołoski na granicy został zaatakowany, a żołnierze wołoscy pobici. Następnie Polacy doszli do Buzau, które zniszczyli. Kiedy hospodar wołoski Radu Mihnea dowiedział się o tym najeździe, wysłał poselstwo do książąt polskich, prosząc, żeby zostawili jego państwo i wrócili do Mołdawii ${ }^{47}$.

Incydent w Buzau pod wieloma względami stał się punktem zwrotnym w całej wojnie. Stało się jasne, że trzeba było zrobić coś z Mołdawią, bo to nie mogło dalej tak trwać. Z jednej strony bezwarunkowe wsparcie przez Turków Stefana Tomży II mogło sprowadzić na nich nowe kłopoty. Elity polityczne na Wołoszczyźnie nie traciły nadziei na przywrócenie na tron hospodarski swego faworyta Radu Szerbana tak długo, jak jeszcze ży $4^{48}$. Incydent w Buzau mógł stać pretekstem do wybuchu nowej wojny, w której uczestniczyliby nie tylko Polacy i Turcy, ale i Habsburgowie. To z kolei mogło doprowadzić dla rozszerzenia działań wojennych także na Siedmiogród. Dopóki do starć militarnych dochodziło na terenie Mołdawii, sytuację można było mniej więcej kontrolować. Poszerzenie konfliktu poza granice Mołdawii mogło przynieść nieobliczalne skutki.

Mniej więcej w tym samym czasie w Jassach umarł Michał Wiśniowiecki. Za winnego jego śmierci uznano pewnego greckiego księdza prawosławnego, którego oskarżono o otrucie księcia49.

Po powrocie do Jass z kampanii na Wołoszczyźnie Samuel Korecki zdawał sobie sprawę z bardzo skomplikowanej sytuacji, w której znalazł się wraz ze swym wojskiem i młodym hospodarem. Z tego powodu napisał kilka listów, w których pokazywał nieuniknioność podjętych działań. Z 6 maja I6ı6 r. znane są dwa listy: jeden do szlachty ${ }^{50}$ a drugi do Janusza Radziwiłła $^{51}$, w których Korecki opowiadał o ostatnich wydarzeniach i o krokach, które podjął dla osiągnięcia ostatecznego sukcesu. Upewniał szlachtę, że Turcy z powodu problemów z Persją nie podejmą poważnych działań w Mołdawii, a Janusza Radziwiłła prosił, żeby ten bronił go na sejmie tym bardziej, że sam nie będzie mógł w nim uczestniczyćs².

\footnotetext{
44 „li Polachi non solo hanno scacciato Steffano Vaivoda dalla Bogdania, ma che siano anco penetrati nella Valachia" (ibidem, 4, cz. 2, s. 356, nr 381).

45 Veress, 9, s. 79-80, nr 69.

46 Documente privitoare la istoria României, Seria A. Moldova, veacul 17, t. 4: 1616-1620, Bucureşti 1951, nr 8, 9.

47 Tesaur 2, s. 57-60.

48 Francuski żolnierz Joppecourt pisał trochę później, że podczas kampanii na Wołoszczyźnie delegacja wołoskich bojarów poprosiła Aleksandra, by został ich hospodarem, a gdyby nie zechciał, prosili o pozwolenie Radu Szerbanowi na przejazd przez Mołdawię i powrót na tron wołoski: Tesaur 2, s. 59.

49 Tesaur 2, s. 45.

50 Corfus I., Documente culese din arhive polone. Secolele al XVI-lea şi al XVII-lea, red. V. Matei, Bucureşti 2001, s. 230-233, nr 110 .

51 B.PAN Kórnik, rkps1540, k. 28-29.

52 „Teraz dla uspokojenia przyległych sąsiadów nie mogąc się na ten sejm teraźniejszy stawić, tę skończoną wojnę pod obronę WXM mego Mpana podawam” (B.PAN Kórnik, rkps 1540, k. 29).
} 
Sytuacja, która powstała w Mołdawii, została zanalizowana na sejmie, który rozpoczął obrady 27 kwietnia. Już wtedy pojawiły się dwa obozy, różniące się stosunkiem do kampanii mołdawskiej. Pierwszy wspierał aktywne działania w rozwiązaniu problemu mołdawskiego. Chodziło tu przede wszystkim o mianowanie na tron Mołdawii hospodara, który byłby przyjacielem Polaków i który by nie pozwolił na zniszczenia i rabunek ziem ukraińskich, prowadzone przez opryszków i Tatarów korzystających ze szlaku mołdawskiego. Drugi obóz nie wspierał żadnych aktywnych działań i uważał, że polepszenie sytuacji w Mołdawii można osiągnąć przez rozmowy z Turkami.

Jednak głównym problemem sejmu warszawskiego I6ı6 roku stało się uchwalenie nowych podatków na organizację kolejnej kampanii moskiewskiej. Oczywiście, większość szlachty uznała za ważniejszą sprawę moskiewską niż mołdawską. Ponieważ Rzeczpospolita nie była w stanie walczyć na dwa fronty, za priorytet uznany został problem moskiewski. Przed sejmem król i jego otoczenie, w tym Stanisław Żółkiewski ${ }^{53}$, przeciwnik kampanii Mohyłów w Mołdawii, przygotowali opinię publiczną, skarżąc się na zięciów Mohyłów, którzy najechali na Mołdawię i zaproponowali, żeby na przyszłość zakazać takich działań ${ }^{54}$. Na sejmiku w Wiszni postanowiono zwrócić się do króla, by znalazł możliwość zapobieżenia podobnym sytuacjom w przyszłości55. Wśród szeregu pytań i rekomendacji znajdował się i ten, według którego: „Komisja albo poseł aby zaraz na początku sejmu był do cesarza tureckiego wyprawiony, który by Rzeczpospolitą justyfikował i o pokój i bezpieczeństwo, wedle pakt które Korona z nimi ma, traktował, prosimy J. Kr. Mci”56.

Na otwarciu sejmu kanclerz koronny Feliks Kryski w swej mowie zaliczył do pierwszorzędnych problemów Rzeczypospolitej to, że istnieje niebezpieczeństwo tureckie dla Polski z powodu swawoli niektórych Polaków. Z powodu tych działań sułtan turecki chciał nawet zerwać pokój. Myślał o tym już wcześniej, jednak teraz, mając pokój z Persami, może skoncentrować swoje wojsko na granicy Rzeczypospolitej. Według kanclerza koronnego, Skinder pasza miał Iooooo ludzi. Oprócz działań książąt, którzy narażają Rzeczpospolitą na wielkie niebezpieczeństwo, to samo robią i Kozacy. Na każdym sejmie jest o tym mowa, że swawola doprowadzi do ruiny Rzeczypospolitej. Z tego powodu zrodziły się wojna moskiewska i wojna turecka ${ }^{57}$. Wnioskując, stwierdzał, że do Porty musi być wysłany poseł, który by przekonał Turków, że książęta weszli do Mołdawii dla własnej korzyści. Ani król, ani jego otoczenie nie mieli zamiaru wspierać kandydatury Aleksandra Mohyły na tron Mołdawii.

\footnotetext{
53 O zainteresowaniu Stanisława Żółkiewskiego sprawami mołdawskimi i o jego stosunku do działań Wiśniowieckiego i Koreckiego pisał między innymi Zbigniew Ossoliński, w swoim Pamiętniku (opracował i wstępem poprzedził J. Długosz, Warszawa 1983, s. 68-69).

54 Corfus I., Documente..., s. 228, nr 108.

55 AGZ, t. 20, s. 152-158, nr 105: „Ważyli się tego prywatni ludzie, że przeciw woli i zakazom króla Imci p.n. tudzież i przeciw prawu samemu wojska prywatnie zebrawszy ausu temerario do Wołoch weśli, ziemie tamte pustoszyli, ludzi wiele pomordowali i na państwo tamto hospodarczyka wedle myśli swej wsadzili, czem wielkie niebespieczeństwo na Rzpltą zaciągnęli. Prosimy J.kr.Mci, aby serio animadwertować raczył, żeby się tym przykładem nikt na potem tego czynić nie ważył, a kiedyby szkód swoich dochodzić mieli ci Ich Mć, którzy są ukrzywdzeni, niechaj to sejm deklaruje" (s. 155).

56 Ibidem, s. 154. Stąd wynika, że nie chodziło o utwierdzenie Aleksandra Mohyły na tronie hospodarskim Mołdawii, lecz tylko o pokój pomiędzy Rzecząpospolitą a Imperium Osmańskim.

57 Hurmuzaki, supl. 2, t. 2, s. 399-414, nr 205.
} 
Główne wysiłki króla były skierowane na Moskwę, a nowe podatki były przeznaczone na armię, która miała osadzić Władysława na tron moskiewski ${ }^{8}$.

Oprócz działań w Mołdawii ważne znaczenie miały także wydarzenia w innych państwach tego obszaru - w Siedmiogrodzie i Wołoszczyźnie. Trzy państwa były powiązane między sobą, a wyniki walki w jednym państwie mogły oddziaływać na pozostałe.

Zawarcie umowy osmańsko-austriackiej z pomocą Gaspara Grazzianego, przyszłego hospodara Mołdawii, nie położyło kresu próbom zdobycia tronu siedmiogrodzkiego, podejmowanym przez różnych pretendentów. Jest sprawą oczywistą, że mieli oni wsparcie co najmniej części dygnitarzy austriackich. To, co jest bardzo interesujące w tym przypadku, to że działania w Mołdawii oraz próby przywrócenia na tron hospodarski Radu Szerbana i otrzymania tronu siedmiogrodzkiego przez George'a Drugeth de Homonnaya pochodzą mniej więcej z tego samego czasu. 7 marca I6I6 r. ambasador Wenecji pisał o próbach Homonnaya zdobycia tronu siedmiogrodzkiego ${ }^{59}$.

Ówczesny książę siedmiogrodzki, Gabor Bethlen, pisał do swych poddanych, że w tym okresie otrzymał rozkaz wsparcia osmańskiej kampanii w Mołdawii i żądał koncentracji w obozie obok Klużu6 ${ }^{6}$ W tym samym czasie pojawiły się wzmianki o zamiarach George'a Drugeth de Homonnaya i Radu Szerbana zaatakowania Bethlena z dwóch stron: od Mołdawii i ze strony Munkacza ${ }^{61}$. 9 maja I6ı6 r. Gabor Bethlen pisał do Franciszka Redeya o przeciwdziałaniu tym planom ${ }^{62}$. Ambasador Wenecji w Wiedniu pisał, że pomysł Homonnaya sprowadził dużo kłopotów na Habsburgów, ponieważ był wspierany przez dużą liczbę szlachty węgierskiej63. Ze swojej strony, 22 maja I6ı6 r. Radu Szerban - były hospodar Wołoszczyzny - pisał do barona Ioana Molarta, że jest przygotowany do kampanii, która ma duże szanse powodzenia, jako że armia osmańska jest zajęta wojną z Persją: „,illa praesidia Turcica... ingruente bello Persico in Asiam transportata esse". Gabor Bethlen sprzyjał pojawieniu się pogłosek, że Szerban będzie walczył z kalwinami w Siedmiogrodzie ${ }^{64}$. Inna dezinformacja dotyczyła zgody Turków na kampanię na Wołoszczyźnie. Spośród innych listów warto przywołać jeszcze i ten, w którym Georghe Thurzo pisał do Bethlena, że Szerban ma pozwolenie od Turków na powrót do Wołoszczyzny ${ }^{65}$.

Rekrutacja wojska dla Szerbana nie osiągnęła poważnego poziomu, a żołnierze, już zebrawszy się, zaczęli zwyczajne rabowanie ludności cywilnej ${ }^{66} .23$ maja I6I6 r. poseł Wenecji w Wiedniu pisał o wejściu Homonnaya do Siedmiogrodu z I000o żołnierzy ${ }^{67}$. Wojenne przygotowania nie były sekretem dla władz osmańskich, a w czerwcu do Wiednia wysłano poselstwo. Władze austriackie zostały napomniane, by zachować „święty pokój”.

\footnotetext{
58 Ibidem, s. 399-414, nr 350-652.

59 Ambasador Wenecji w Wiedniu, Documente privitoare la istoria românilor, culese de Eudoxiu Hurmuzaki, t. 8: 1376-1650, Bucureşti 1894 [dalej: Hurmuzaki, 8] s. 373, nr 548.

60 Veress, 9, s. 81-83, nr 71.

61 Bethlen do Zygmunda Forgacha, dygnitarza austriackiego, 8 V 1616 r. (ibidem, s. 83-85, nr 72).

62 Ibidem, s. 85, $\mathrm{nr} 73$.

63 Hurmuzaki, 8, s. 373, nr 549.

64 Veress 9, s. 86-88, nr 75.

65 Ibidem, s. 93, $\mathrm{nr} 81$.

66 Ibidem, s. 89, nr 77.

67 Hurmuzaki, 8, s. 374, nr 550.
} 
Przypomniano, że kwestia przywrócenia tronu Wołoszczyzny Radu Szerbanowi zależy od woli sułtana ${ }^{68}$. Ali pasza Madiaroglu objaśnił pozycję władz osmańskich - ani Homonnay, ani Szerban nie mają zezwolenia tureckiego na otrzymanie tronów Siedmiogrodu i Wołoszczyzny, a wszelkie działania w tym sensie znaczyły naruszenie pokoju podpisanego w Zsitvatorok w I606 r.69. W tej sytuacji urzędnicy habsburscy obiecali, że nie będą wspierali ani Homonnaya ani Szerbana ${ }^{70}$. I3 czerwca I6I6 r. przyszła nowina o zwycięstwie Bethlena nad Homonnayem na granicy Siedmiogrodu, przy czym książę miał wsparcie wojsk tureckich ${ }^{71}$. I6 czerwca I6ı6 r. Andrzej Doczy pisał do cesarza Macieja I, że Radu Szerban znajdował się w Munkaczu z wojskiem liczącym tylko I50o żołnierzy ${ }^{72}$. Epilog kampanii byłego hospodara Wołoszczyzny nastąpił w końcu czerwca I6I6 r., kiedy został on zmuszony do szukania powodzenia w Polsce, żeby, korzystając z wojny polsko-mołdawskiej, moc wrócić na tron Wołoszczyzny, jednak również bez żadnego powodzenia ${ }^{73}$.

W Mołdawii Aleksander Mohyła kontynuował wysiłki zmierzające do uznania go za hospodara. Jednak te starania, w których korzystał z usług dyplomatów Francji, Wenecji i Holandii nie doprowadziły do zamierzonego skutku ${ }^{74}$. Pieniędzy wysyłanych przez ambasadora Francji wielki wezyr nie zechciał przyjąć ${ }^{75}$. Poseł polski Kochański, który miał zalecenie od sejmu, by polepszyć stosunki polsko-osmańskie, nalegał, żeby hospodarstwo mołdawskie było oddane innemu sąsiadowi, lepszemu niż Stefan Tomża II ${ }^{76}$.

Wtedy już los Stefana Tomży II był przesądzony. Z 6 czerwca I6I6 r. pochodzi wzmianka, że były hospodar został aresztowany i stracił cały majątek ${ }^{77} .25$ czerwca I6I6 r. hetman polny informował szlachtę o rychłej kampanii osmańskiej w Mołdawii przeciwko książętom i Mohyłom ${ }^{78}$.

Kiedy dowiedziano się, że Tomża został usunięty z tronu mołdawskiego, w Jassach odbyła się wielka uroczystość 79 . Aczkolwiek już wtedy mówiono o trzeciej osobie, która mogłaby

\footnotetext{
68 Ibidem, s. 374, nr 551.

${ }^{69}$ Ibidem, s. 95-97, nr 83. Ekscerpt z listu Ali paszy do Zygmunta Forgacha, w: Documente privitoare la istoria românilor, culese de Eudoxiu Hurmuzaki, t. 4, cz. 1: 1600-1649, Bucureşti 1882 [dalej: Hurmuzaki, 4, cz. 1] s. 569, $\mathrm{nr} 488$.

70 Hurmuzaki, 4, cz. 1, s. 570, nr 499; s. 571, nr 450.

71 Veress, 9, s. 102, nr 87.

72 Ibidem, s. 102-103, nr 88.

73 Lupta pentru unitate naţională a Ţărilor Române (1590-1630), Documente externe, red. R. Constantinescu, Bucureşti 1981, s. 161, nr 303; s. 255, nr 304 - jest informacja, że podczas bitwy pod Dragszani, Szerban przychodził na pomoc z wojskiem, które liczyło 2000 żołnierzy, chociaż przypuszcza się, że ta liczba jest zawyżona.

74 N. Iorga, Doamna lui Ieremia Movilă, s. 1064-1065, nr 29; Hurmuzaki, 4, cz. 2, s. 357-359, nr 383. Pismo od Aleksandra napisano po łacinie, ibidem, s. 358-359.

75 „detto Ambasciator di Francia offeri a nome di esso Alessandro una buona summa de dinari al Caimecan, ma non le riusci" (ibidem, s. 359-360, nr 384).

76 ,le fu dimandato dal Caimecam quello che sapesse di questi prigioni soldati stipendiali del suo Re, rispose che replicava quello che havea detto a lui medesimo nella prima audienza cioè, che di questi moti di Bogdania il suo Re non ne havea parte alcuna... ma che ben e'vero chè Sua Maesta «Sultan turecki n.ns.»" alcun'altro che vicinasse meglio, di quello che ha fatto esse Steffano" (Hurmuzaki, 4, cz. 2, s. 360, nr 385).

77 Veress, 9, s. 274, nr 218.

78 Hurmuzaki, supl. 2, t. 2, s. 414-417, nr 206.

79 Tesaur 2, s. 63-64.
} 
stać się hospodarem mołdawskim. Jednym z kandydatów był Gabriel Mohyła, syn Szymona Mohyły, wspierany przez Stanisława Żółkiewskiego ${ }^{80}$.

Po usunięciu problemu ze strony Homonnaya i Szerbana, Turcy zyskali możliwość rozwiązania kwestii mołdawskiej. Chociaż poseł polski nalegał, żeby tron mołdawski został oddany Gabrielowi Mohyle, pojawiło się inne rozwiązanie tego problemu. Na tron mołdawski został mianowany Radu Mihnea, od I6I hospodar Wołoszczyzny ${ }^{81}$. Poseł Holandii w Konstantynopolu twierdził, że „Korecki miał zamiar walczyć do końca, bo zrujnował i siebie i swych przyjaciół" "82.

Ostateczna bitwa rozegrała się 23 lipca - 3 sierpnia I6I6 r. w Dragszani, w powiecie Hârlău. Polska armia organizowała obronę w obozie. Na początku została otoczona przez turecką armię. Artyleria turecka zabiła kilku Polaków, a z kolei atak kawalerii turecko-tatarskiej doprowadził do kolejnych problemów w obronie. Odpowiedź polskiej artylerii była bardzo skromna z powodu braku dział i prochu. Po kolejnym ataku kawalerii turecko-tatarskiej obóz polski skapitulował ${ }^{83}$. Korecki dostał się do niewoli, z której uciekł. Elżbieta Mohyłowa i obaj jej synowie, Aleksander i Bogdan, zostali zmuszeni do przyjęcia islamu. Tak skończyła się dynastia Jeremiego Mohyły, jednak nie walka o polskie wpływy w Mołdawii. Nowy układ, zawarty z nowym hospodarem Radu Mihnią, powtarzał układy poprzednich hospodarów, chociaż kolejne lata będą początkiem jeszcze większych walk o Mołdawię pomiędzy Polakami a Turkami.

\section{The Moldavian campaign in late 1615 and first half of 1616 and its influence on the Polish-Ottoman relationship}

\section{Abstract}

The Moldavian campaign in late I6I5 and first half of I6I6 caused a growing tension in the relations between the Republic of Poland and the Ottoman Empire. The Turkish sultan was determined to defend his interests in Moldova. At the same time, the Polish king tried to gain the throne of Moscow. The Polish magnates, Michał Wiśniowecki and Samuel Korecki, married to daughters of Elisabeta Movilă, decided to put their brother-in-law, Alexander Movilă, on the throne of Moldavia. But Hetman Stanisław Zółkiewski and king Sigismund III were against this campaign and did not provide any support. The intervention in Moldova could have had serious consequences for both the Turks and the Tatars. The war ended in the defeat of the magnates.

Key words: Moldavia, Ottoman Empire, Poland, I7th century, Stefan II Tomsa, the Movileşti

\footnotetext{
80 „Di Constantinopoli delli 28 Maggio scrivono che vi era gionto un ambasciator Polacco per far instanza al Gran Signore che voglia confirmar per Vaivoda di Moldavia il figliolo del già Simone posto da Polachi in Moldavia in luoco del Tomsa, ma pareva che Sua Altezza «sultan turecki n.ns.» non ne volese ciò sentire" (Veress, 9, s. 110, nr 93).

81 „della stipre di quei prencipi”; myślano, że nowym hospodarem mógł zostać Aleksander syn Radu Mihnii, tylko że on był za młody: ,avero, che crearanno il figliuolo del medesimo Radolo, ma l'esser egli in età molto tenera li pregiudica grandemente" (Hurmuzaki, 4, cz. 2, s. 362, nr 388).

82 N. Iorga, Doamna lui Ieremia Movilă, s. 49, nr 37.

83 Tesaur 2, s. 74-77.
} 


\section{BIBLIOGRAFIA}

\section{Źródła Rękopiśmienne}

Biblioteka PAN w Kórniku, rkps I540, k. 28-29.

Biblioteka PAN w Kórniku, rkps nr 324, k. I87v-I88r.

Biblioteka PAN w Kórniku, rkps nr 324, k. I88r.

\section{Źródła drukowane}

Akta Grodzkie i Ziemskie z Archiwum Ziemskiego we Lwowie, t. 24: Lauda Sejmikowe Halickie (1575-1695), wyd. A. Prochaska, Lwów I93I.

Akta Grodzkie i Ziemskie, t. 20: Lauda sejmikowe, t. I: Lauda wiszeńskie (I572-I648), oprac. A. Prochaska, Lwów I909.

Corfus I., Documente culese din arhive polone. Secolele al XVI-lea şi al XVII-lea, red. V. Matei, Bucureşti 200I.

DIR, Seria A. Moldova, veacul I7, t. 4: I6I6-I620, Bucureşti I95I.

Documente privitoare la istoria Ardealului, Moldovei şi Ţării Româneşti, t. 9: I6I4-I636, Acte şi scrisori, red. A. Veress, Bucureşti 1936.

Documente privitoare la istoria românilor, culese de Eudoxiu Hurmuzaki, t. 4, cz.I: I6ooI649, Bucureşti I882; t. 4, cz. 2: I600-I650, Bucureşti I884; t. 8: I376-I650, Bucureşti I894; t. I5: Acte şi scrisori din arhivele oraşelor ardelene (Bistriţa, Braşov, Sibiu), red. N. Iorga, cz. 2: I60I-I825, Bucureşti I9I3; supl. I, t. I: I5I8-I750, red. Gr. G. Tocilescu, A. I. Odobescu, Bucureşti I886; supl. 2, t. 2: I60I-I640, red. I. Bogdan, tłum. francuskie I. Skupiewski, Bucureşti I895.

Iorga N., Doamna lui Ieremia vodă, „Analele Academiei Române. Memoriile Secţiunii Istorice", seria 2, 32/19I0, s. I-I05.

Iorga N., Studii şi documente cu privitoare la istoria românilor, vol. IV, Bucureşti 1902.

Joppecourt Ch., Istoria scurtă şi adevărată a celor mai memorabile lucruri întâmplate în tulburările din urmă ale Moldovei, w: A. Papiu Ilarian, Tesauru de monumente istorice pentru România, t. 2, Bucureşti I863, s. 20-I24.

Ossoliński Z., Pamiętnik, opracował i wstępem poprzedził J. Długosz, Warszawa 1983.

Pisma Stanisława Żółkiewskiego, wydał A. Bielowski, Lwów I86I.

\section{Opracowania}

Bobicescu C., Intre integrare și păstrarea autonomiei. Modelul polonez și controlul domnilor în Moldova și Țara Românească la cumpăna secolelor XVI-XVII, w: Movileştii. Istorie şi spiritualitate românească. Vol.II. Ieremia Movilă. Domnul. Familia Epoca, red. Șt. S. Gorovei, Suceviţa 2006, s. 227-248.

Constantinov V., Bitwa pod Sasowym Rogiem i jej wpływ na relacje polsko-osmańskie w I6I2 roku, w: Wybrane problemy badawcze historii wojskowej. W pancerzu i mundurze, red. K. Kościelniak, Z. Pilarczyk, Toruń 20I4, s. IOI-I27.

Constantinov V., Cetatea Hotinului în disputele politico-militare polono-otomane din perioada I6I2-I62I, „Cohorta”, 20I5, nr I, S. 4I-56.

Constantinov V., Działania wojenne w państwach rumuńskich $w$ roku I6II i ich konsekwencji w ówczesnych stosunkach polsko-tureckich, w: Studia historyczno-wojskowe, t. I, red. M. Wagner, Siedlce 2006, s. 49-56. 
Constantinov V., Stosunki polsko-mołdawskie za czasów hospodarstwa Stefana Tomszy II (I6I2-I6I5), „Saeculum Christianum”, 2I/20I4, S. II4-I2O.

Constantinov V., Țara Românească și Țara Moldovei în timpul domniilor lui Radu Mihnea, Iași 2007.

Constantinov V., The political and military realities Nothward Danube in I6I2, w: Studia $z$ dziejów stosunków z Państwem Moskiewskim w XVI-XVII wieku, red. M. Nagielski, Zabrze-Tarnowskie Góry 20I3, s. I48-I62.

Lupta pentru unitate naţională a Ţărilor Române (I590-I630), Documente externe, red. R. Constantinescu, București I98I.

Łoziński W., Prawem i lewem. Obyczaje na Czerwonej Rusi w pierwszej połowie XVII wieku, Warszawa 2008.

Milewski D., A campaign of the great hetman Jan Zamoyski in Moldavia (1595), cz.I: Politico-diplomatic and military preliminaries, „Codrii Cosminului”, I8/20I2, nr 2, s. 26I-286.

Milewski D., A Campaign of the great hetman Jan Zamoyski in Moldavia (1595), cz. 2: The Battle of Tुţora and aftermath, „Codrul Cosminului”, I9/20I3, nr I, s. 57- 76.

Milewski D., Mołdawia między Polska a Turcją. Hospodar Miron Barnowski i jego polityka (I626-I629), Oświęcim 2014.

Pippidi A., Quellques drogmans de Constantinople au XVIIe siecle, "Revue des Etudes Sud-Est Europeenes", IO/I972, nr 2, s. I35-I45. 